\title{
THE CONCEPT OF LONE-WOLF TERRORISTS
}

\begin{abstract}
The nature of terrorism has changed significantly over the last decade. In recent years, the phenomenon of so-called lone wolf terrorism has increased with more and more attacks perpetrated by single actors. The shifting nature of terrorism has prompted a debate over how to accurately describe individuals that act independently of a terrorist organization's chain of command. The lone wolf concept needs to be re-evaluated and adapted to changed circumstances. The purpose of this paper will be focused on one of the most unpredictable forms of terrorism acts - those committed by a single individual, a so-called "lone wolf terrorist". Politically, the concept lone wolf is used to reassure the public and communicate that the danger is no longer immanent. Academically as well as practically, the concept entails more than this reassurance. The most difficult part in detecting a lone wolf is that their attacks occur in the context of multiple ideological frameworks and are not confined to a single group or system of belief. Currently, there are more questions than answers on the content and validity of the lone wolf concept, but we should be alert and aware that the external conditions have changed, and old responses may not be appropriate anymore to present-day lone actor terrorism.
\end{abstract}

Keywords: LONE-WOLF TERRORISTS, EXTREMISM, ATTACKS, THREAT, RADICALIZATION

\section{Introduction}

Recent events have brought increased attention to a relatively rare form of terrorism: lone-wolf terrorists. Lone-actor terrorists are those who plan and carry out an attack without assistance from others. They see themselves as representing some larger group or cause and may have some experience in a group, organisation or social movement related to this cause. Their grievance is thus shared by many, although their attack is carried out alone (McCauley, S, Moskalenko, 2014).

The concept of the lone wolf terrorist is increasingly common in recent decades, often attracting media attention as a "new" and "dangerous" threat. It is a growing phenomenon, but research on this topic has been accompanied by major shortcomings, because this type of violence may be one of the most mysterious and unforeseeable forms of terrorism (Krstic, 2018). 


\section{Defining the Concept}

Lone wolf terrorists are risking life and liberty for their cause. Why would any individual take this kind of risk? More generally, why would any individual choose to sacrifice for a cause? (McCauley, S, Moskalenko, 2014).

Answering this questions requires, first and foremost, an in-depth, evidence based understanding of the evolution of lone wolf terrorism, the radicalization of lone wolves, and the socio-political contexts within which the phenomenon is situated.

This paper intentions to provide such insight. In so doing, it seeks to offer significant steps toward prevention by providing new ways of thinking about and responding to lone wolf terrorism. This demands a clear definition of the phenomenon, and one that distinguishes how lone wolf terrorism differs from other types of terrorism.

A precise definition of lone wolf terrorism is imperative, especially because the term is often misused or used imprecisely. Here "lone wolf terrorism" refers to terrorist actions carried out by lone individuals, as opposed to those carried out on the part of terrorist organizations or state bodies. The element of terrorism highlighted in this distinction - namely, the subject who commits terroristic violence (an individual) - follows in the tradition of researchers who define the lone wolf as "a person who acts on his or her own without orders from-or even connections to-an organization." (Burton, Stewart, 2008).

Under this formulation, a lone wolf is not one who conspires with others in an attempt to commit terrorism. The lone wolf is solitary by nature and prefers to act totally alone, although his or her radicalization to action maybe spurred by violent media images, incendiary books, manifestos, and fatwas (Hamm, Spaaij, 2017).

In this paper radicalization is defined as the process by which individuals adopt extreme views, including beliefs that violent measures need to be taken for political or religious purposes. While acting independently, the lone wolf is nevertheless a political creature who is not pursuing purely egocentric goals (Hoffman, 2006).

There is no professional consensus on the definition of lone wolf terrorism, and some scholars reject the term altogether. For example, Jonathan White (2003), argues that the term has little practical value. "Some lone wolves are better viewed as true believing extremists who go off the deep end," he observes. "The term glorifies their actions and should not be used." White is not alone in his critique. The veteran terrorism researcher Brian Jenkins (2011) also argues that "lone wolf terrorism" is "a romanticizing term that suggests a cunning and deadly perpetrator" when that is not always the case. To avoid this perceived glorification, researchers often refer to the pheno- 
menon with such pseudo-scientific buzzwords as "lone-actor terrorism," "solo actor terrorism", "single-actor terrorism," "solitary terrorism," "freelance terrorism," "self-starter terrorism," "lone avenger terrorism, "or "lone wolf actor terrorism,".

Some experts use an expansive definition of lone wolf terrorism in terms of both motives and the number of perpetrators involved. Jeffrey Simon (2013), defines the crime as the use of violence against the government, society, business, or the military by an individual acting alone "or with minimal support from one or two other people" in support of political, social or financial goals. This definition includes what Simon calls the "criminal lone wolf" or "those who perpetrate their violence for purely personal or financeal gain."

Whereas "hate crime" refers to a range of both violent and nonviolent offenses that are committed due to the perpetrator's prejudice against a particular group represented by the victim, terrorism is a violent act intended exclusively to coerce a government or civilian population in the furtherance of political or social objectives (Turpin-Petrosino, 2015).

While the lone wolf 's ideological motivation partially explains why this figure has received hyperbolic attention in academic circles, it is the very status of the "loner" that makes this terrorist unique, poorly understood, and, most importantly, unpredictable in his or her selection of targets for violence. Due to their lack of terrorist training and supporting manpower, lone wolves usually avoid hard targets (such as well fortified government buildings) in favour of simpler attacks against undefended soft targets (such as public gatherings). These characteristics distinguish terrorism committed by unaffiliated individuals from that perpetrated by broader radical movements. Far more than a figure of speech, then, "lone wolf terrorism "is an epistemological recognition of the methods, validity, and scope of this particular form of political violence (Hamm, Spaaij, 2017).

Paul Gill (2015) considering three categories:

1. individual terrorists who train alone and select their own targets;

2. individuals who received training from terrorist organizations and were given targets for an attack;

3. and couples who may have radicalized each other, but who received no external direction.

Similarly, other experts, such as Christopher Hewitt (2003), have defined a terrorist group as consisting of at least four people; anything less is considered a lone wolf operation. In this definition, couples and trios are also counted as lone wolf terrorists.

Arguably, if two or three people carry out an act of terrorism, then it is no longer a "lone" act committed by an "unaffiliated" individual since 
there were multiple perpetrators who were at least affiliated with one another. The other issue relates to violent radicalization. In cases of lone wolf terrorism, an aggrieved individual typically becomes radicalized within his or her own attainable means, such as violent media imagery, online sermons and political screeds, or personal veneration of terrorists who came before (Spaaij, 2012). Small terrorist groups (including couples or trios) have a different kind of dynamic whereby radicalization occurs with the conspiratorial aid of other group members (Hamm, 2002).

Regardless of how small such dyads, triads, or small cells may be, as soon as two or more people interact with one another with the aim of committing a terrorist attack, small-group dynamics come into play (Pantucci, 2011).

\section{Lone wolf attacks and propaganda}

The lone wolf terrorist is typically someone who acts out of a strong ideological or religious conviction, carefully plans their actions, and may successfully hide their intentions from others.

Police Commissioner Bill Bratton told reporters that compared to attacks by al- Qaeda, "ISIS would be much more into the inspiration of the lone wolf... They're very sophisticated in their capabilities through their videos, through their social media, through their magazines." (NYPD, 2014).

The first ISIS-inspired lone wolf attack in America came on September 26, 2014, when thirty-year old Alton Nolen beheaded a co-worker ata food processing plant in Oklahoma. A prison convert to Islam whose digital footprint involved ISIS propaganda.

ISIS's explicit call for Western supporters to carry out "lone wolf" attacks in their home countries became a core part of the group's propaganda over the next two years.

Investigators say the terrorist attack on two mosques in New Zealand was carried out by a single perpetrator. But referring to him as a "lone wolf" deceptively conceals a breeding ground of extreme-right terror. (Petersmann, 2019, DW).

Norwegian terrorist Anders Behring Breivik, who murdered 77 people on July 22, 2011, is often cited as a prototypical "lone wolf" perpetrator of terrorist attacks (Berntzen, Sandberg, 2014). "Europe is becoming increasinggly familiar with attacks by extremists, but Breivik's actions made him the deadliest lone wolf attacker in the continent's history" (Seierstad, 2016).

"The idea that terrorists operate alone allows us to break the link between an act of violence and its ideological hinterland" (Burke, 2017). He believes that the lone wolf theory "implies that the responsibility for an individual's violent extremism lies solely with the individual themselves." 
Modern terrorists may not always belong to a group that can be clearly named such as al-Qaida, the "Islamic State" or the National Socialist Underground (NSU), an extreme-right German terrorist cell that was responsible for a string of murders. Nevertheless, their radicalization takes place in the social climate in which they live. The internet and social media allow terrorists unprecedented ways to network globally and the ability to propagate their ideologies - right up to livestreaming their attacks on Facebook, as was the case with the Christ church attack.

Most experts agree that terrorists are products of their time. An increase in intolerance has established itself in recent years as a global social trend, fuelled by political discourse that is becoming increasingly populist. The yearning for simple answers polarizes; strangers and those with different viewpoints quickly become enemies. Extremism is taking root in mainstream society - a trend that is reinforced with the digitalization of human life.

Real relationships are replaced by virtual ones. But even online interactions have real consequences. David Sonboly, who murdered nine people at a Munich shopping mall on July 22, 2016, was heavily involved in online xenophobic networks. Sonboly deliberately chose the fifth anniversary of Breivik's terrorist attack as the date for his shooting. He received praise from certain circles of like-minded people for the choice of date (Petersmann, 2019, DW).

Some jihadi attackers who struck in Europe were presumed to be lone wolf perpetrators who idealized IS, but actually had virtual contact with IS members in Syria and Iraq immediately before carrying out their attacks.

Should Christ church attacker Tarrant actually prove to be the author of the 74-page manifesto, then he is explicitly making parallels between himself, Breivik and Dylann Roof, the white supremacist who shot nine black churchgoers in Charleston, South Carolina on June 17, 2015.

It is known that both Breivik and Tarrant were in contact with other far-right extremists at home and abroad, both in real life and online. Tarrant in particular has travelled extensively, including in Europe. On his Facebook profile, which has since been deleted, he shared extremist content and articles about right-wing extremists from Europe, including at least one report on right-wing extremist soldiers in the Bundeswehr - Germany's armed forces - who for him are apparently kindred spirits.

Breivik and Tarrant view themselves as modern-day crusaders in the battle to preserve the purity of an allegedly threatened white European breed. Both regard Muslims in particular to be "invaders" who strive for world domination (Petersmann, 2019, DW).

Membership in groups and "acting alone", however, are concepts increasingly difficult to apply in a world where terrorist organizations increasingly organize virtually through social media. 
We found that social ties play a crucial role throughout the process leading from ideological radicalization to the planning and preparation of terrorist attacks (Schuurman. B, et al. (2017).

\section{Clarifying the role of motivation in lone-wolf terrorism}

Islamophobia, racism and white nationalism have long managed to find their way into the upper echelons of western democratic governments, be it in Australia, the US, or Europe.

In this context, a study on 119 individual perpetrators of terrorism was presented by the International Centre for Terrorism Studies (ICST) at Pennsylvania State University in February 2013. According to the study, the vast majority of supposedly "lone actor terrorists regularly engaged in a detectable and observable range of behaviours and activities with a wider pressure group, social movement or terrorist organization."

The ICST study drew another dramatic conclusion: "In the time leading up to most lone-actor terrorist events, evidence suggests that other people generally knew about the offender's grievance, extremist ideology, views and/or intent to engage in violence." (International Centre for Terrorism Studies, 2013). For a large majority (83 percent) of offenders, others were aware of the grievances that later spurred their terrorist plots or actions. In a similar number of cases (79 percent), others were aware of the individual's commitment to a specific extremist ideology. In 64 percent of cases, family and friends were aware of the individual's intent to engage in a terrorism-related activity because the offender verbally told them." (International Centre for Terrorism Studies, 2013).

Lone wolves do not view themselves as lone wolves; precisely the contrary holds true. Lone wolves often perceive themselves as part of a heroic avant-garde seeking to protect a larger group of people. It is important to understand that lone wolf is a label attached to an individual by external forces not the actor himself. One could argue that this by itself does not render the above-mentioned criteria invalid, as objectively the individual was acting alone, regardless of whether he or she believes to belong to an organization or take action on behalf of a group or not. The Norwegian terrorist Anders Breivik, who killed seventy-seven people in 2011, and the "Unabomber" Ted Kaczynski who killed three and injured twenty-three people over a span of seventeen years, are frequently used as typical examples of the lone actor threat. Both were solitary individuals who proved capable of planning and executing deadly terrorist attacks on their own (Hemmingby, Bjørgo, 2016).

The implications of these findings for the prevention and disruption of lone actor extremism can be illustrated by looking at lone actor radicalization and pre-attack behaviour. 
In this paper, lone actor radicalization is studied from a relational perspective. This allowed us to identify varying degrees and types of "loneness" vis-a-vis radical milieus and groups in on and offline settings. Their loneness is, in several instances, reinforced by an exaggerated sense of self-importance, combined with scorn for the efficacy and commitment to the cause of potential co-conspirators. Some are simply alone as a result of significant changes in their social environments (Malthaner et al., 2017).

Similarly, the London nail bomber David Copeland, who embarked on a solo bombing spree in 1999 that left three people dead and 140 injured, may have tried to form a neo-Nazi terror cell before deciding to strike out alone (McLagan, Lowles, 2000).

For example, Mohammed Bouyeri, who murdered the controversial Dutch filmmaker Theo van Gogh in 2004, was a central figure in the jihadist "Hofstadgroup." (Schuurman et al, 2015).

For most individuals, hurting or killing others requires overcoming internal moral barriers to the use of force (Bandura, 1990). Exposure to extremist ideologies and authority figures can play a crucial role in this process and our research found that 78 percent of lone actors were exposed to external sources of encouragement or justification for the use of violence (Schuurman et al., 2017).

The majority of terrorist attacks in the West are not carried out by well-organised international groups. Instead, the terrorist threat in the West largely comes from lone wolf terrorism. Lone wolf terrorists are individuals or a small number of individuals who commit an attack in support of a group, movement, or ideology without material assistance or orders from such group (Simon, 2013). These types of attacks account for 70 per cent of all deaths in the West from 2006 to 2014.

This discrepancy highlights that lone wolf terrorism encompasses awide range of actors with differing motivations, aims and targets. What the data does show is that some countries have much higher levels of lone wolf terrorism than others. The data also demonstrates that lone wolf attacks in Western countries are not exclusively inspired by the calls for international jihad by al-Qa'ida and ISIL (Spaaij, 2012).

From 2006 to 2019 the five largest lone wolf attacks in the West occurred in four different countries. The largest category of lone wolf attacks in the West was political attacks. There were 37 political lone wolf attacks which caused 110 deaths and 135 injuries.

The first example is massacre in the United States when a soldier killed 13 people at a military base in Texas in 2009. The Netherlands also had one attacker commit all terrorist deaths. This occurred in 2009 when an individual drove his car into a crowd to try and damage the bus carrying the Dutch royal family killing seven and injuring 12 people. 
The biggest political lone wolf attack took place in Norway (Borchgrevink, 2012) in 2011when far-right terrorist Anders Breivik conducted two attacks in one day. These killed 77 people including children attending a youth camp run by a political party (Global Terrorism Index, 2015).

The second largest lone wolf attack in USA, occurred in Orlando, Florida. On June 12, 2016, twenty-nine-year-old Omar Mateen stormed a gay nightclub, wielding an assault rifle and a pistol, and carried out the worst terrorist attack since 9/11, killing forty-nine people and wounding another fifty-three. Before he was killed in a police shootout, Mateen shouted to his victims, "It's time to end the bombing in Syria," and then called 911 to proclaim allegiance to ISIS (Alvarez, Perez-Pena, 2016).

The last lone wolf terrorist attack war realized by Australian Brenton $\mathrm{H}$. Tarrant accused of carrying out the massacre at the Al Noor and Linwood mosques - an attack partly broadcast live on Facebook - faces 51 counts of murder and 39 charges of attempted murder. (Graham-Mc Lay, 2019).

Extremist political views were also prevalent in attacks in the United States, with lone wolf attackers motivated by a desire to bring about a political revolution, anarchism and anti-government sentiments, opposition to opponents of gay marriage and opposition to proponents of abortion.

Notable lone wolf terrorist attacks in the West have also included:

$\checkmark$ In 2012, in Brussels, the Imam of a Shiite mosque was killed by a firebomb.

$\checkmark$ On May 2014 again in Belgium, four people were killed by a shooting at the Jewish Museum in Brussels by a former ISIL member.

$\checkmark$ On 7 January 2016 in Paris, a man wearing a fake explosive belt attacked police officers.

$\checkmark$ In June 2016, a man kills a police commander and his partner outside their Paris home (Joscelyn, 2016).

On July 14 2016, Bastille Day, a lone actor drove a cargo truck into a crowd celebrating Bastille Day in Nice, killing 85 people (Global Terrorism Index, 2016).

\section{Table 1. Motivation of Lone-wolf attacks (Global Terrorism Index, 2015).}

CATEGORY

Racial and religious supremacists

\section{SUBCATEGORY}

Anti-Islamic

\begin{tabular}{|c|l|} 
Anti-Islamic & $\begin{array}{l}\text { The target chosen purely because of their } \\
\text { association with Islam. This includes at- } \\
\text { tacks on mosques and retaliation attacks. }\end{array}$ \\
\hline Anti-Semitism & Motivated by a prejudice against Jews. \\
\hline White supremacist & $\begin{array}{l}\text { Motivated by a racist worldview and } \\
\text { could include identification with views }\end{array}$ \\
\hline
\end{tabular}




\begin{tabular}{|c|c|c|}
\hline & & $\begin{array}{l}\text { of the Nazi's } \\
\text { and the KKK. }\end{array}$ \\
\hline \multirow[t]{2}{*}{ Individual issues } & Individual issues & $\begin{array}{l}\text { The attack is due to issues specific to an } \\
\text { individual. This may involve a desire to } \\
\text { gain attention, a particular dogma or ac- } \\
\text { tions relating to particular delusions } \\
\text { stemming from the influence of drugs or } \\
\text { a mental illness. }\end{array}$ \\
\hline & Al-Qa'ida inspired & $\begin{array}{l}\text { Influenced by al-Qa'ida and undertook } \\
\text { an attack without al-Qa'ida's involve- } \\
\text { ment to further the ideology of the gro- } \\
\text { up. }\end{array}$ \\
\hline \multirow[t]{3}{*}{$\begin{array}{l}\text { Islamic } \\
\text { fundamentalism }\end{array}$} & ISIL inspired & $\begin{array}{l}\text { Influenced by ISIL and undertook an at- } \\
\text { tack without ISIL's involvement to fur- } \\
\text { ther the ideology of the group. }\end{array}$ \\
\hline & Jihadism & $\begin{array}{l}\text { Inspired by Islamic fundamentalism to } \\
\text { engage in violence. The attacker may be } \\
\text { inspired by a particular Islamist group, } \\
\text { but is more focused on violent jihadism. }\end{array}$ \\
\hline & Anti-American & $\begin{array}{l}\text { Attack undertaken to express opposition } \\
\text { to specific foreign policies or other acti- } \\
\text { ons by the United States and its allies. }\end{array}$ \\
\hline \multirow[t]{3}{*}{ Political } & Anti-government & $\begin{array}{l}\text { Anti-authoritarian motives for their at- } \\
\text { tack including opposition towards the } \\
\text { police, tax office, post office or other in- } \\
\text { struments of government. Anarchists are } \\
\text { included in this category. }\end{array}$ \\
\hline & Nationalists & $\begin{array}{l}\text { The attacker was inspired by national- } \\
\text { ism. This includes separatists. }\end{array}$ \\
\hline & Political extremism & $\begin{array}{l}\text { Action undertaken to promote a particu- } \\
\text { lar political viewpoint. This may include } \\
\text { stances of immigration, abortion, LGBT } \\
\text { rights or any other view. It is extremist } \\
\text { by definition due to the violence invol- } \\
\text { ved. }\end{array}$ \\
\hline
\end{tabular}

\section{Conclusion}

Today, one of the most challenging and unpredictable forms of terrorism are violent terror acts committed by single individuals, often referred to as lone wolf terrorists or lone actor terrorists. One of the major problems with detecting possible lone wolf terrorists is that there is no consistent or typical profile of a lone wolf. 
However, lone actors' frequent inability to recruit or join others for terrorist purposes does not mean that they drop all social interaction or that their social environment plays no part in their offending. Lone actors typically radicalize in both online and offline "radical milieus". Through such interaction, they develop weak or affiliative social ties with radical actors, even if their integration and socialization in these milieus is often partial, peripheral, and discontinuous.

Essentially, lone wolf attacks represent an undefined threat to national security because they are seemingly impossible to predict or gather intelligence on.

Terrorism as a logic does not differentiate between religions and cultural identities. A mass killer from New Zealand overtook decisive work: terrorism can divide people, but also arouse solidarity. 


\section{References}

Alvarez, L., Perez-Pena, R. (2016). "Praising ISIS, Gunman Attacks Gay Nightclub, Leaving 50 Dead in Worst Shooting on U.S. Soil," New York Times, June 13. Available at: https://www.nytimes.com/2016/06/13/us/orlando-nightclub-shooting.html. [Accessed 15 March, 2019].

Bandura, A. (1990). "Mechanisms of Moral Disengagement in Terrorism," in Walter Reich, ed., Origins of Terrorism: Psychologies, Ideologies, Theologies, States of Mind. Cambridge: Cambridge University Press.

Berntzen, L. E, Sandberg, S. (2014). “The Collective Nature of Lone Wolf Terrorism: Anders Behring Breivik and the Anti-Islamic Social Movement." Terrorism and Political Violence. Vol 26 (5).

Burton, F., Stewart, S. (2008). "The 'Lone Wolf' Disconnect," STRAT FOR Global Intelligence. Available at: http:// www. Stratfor.com/weekly/lone wolf_disconnect. [Accessed 5 Feb.2019].

Burke, J. (2017). "The myth of the 'lone wolf' terrorist." The Guardian. Available at: https:/www.theguardian.com/news/2017/mar/30/myth-lonewolf-terrorist. [Accessed 2 March 2019].

Borchgrevink, A. (2012). A Norwegian Tragedy: Anders Behring Breivik and the Massacre on Utoya. Cambridge: Polity Press.

Brynielsson at al. (2012). Analysis of weak signals for detecting lone wolf terrorists, 2012 European Intelligence and Security Informatics Conference.

Gill, P. (2015). Lone- Actor Terrorism: A Behavioral Analysis. New York: Routledge.

Graham-McLay, C. (2019). "Death Toll in New Zealand Mosque Shootings Rises to 51." The New York Times, May 2.Available at: https://www.nytimes.com/2019/05/02/world/asia/new-zealand-attack-death-toll.html. [Accessed 5 Feb.2019].

Global Terrorism Index. (2015). Measuring and understanding the impact of terrorism. Institute of Economisc and Peace, Sydney.

Global Terrorism Index. (2016). Measuring and understanding the impact of terrorism. Institute of Economisc and Peace, Sydney.

Hamm, M. S. (2002). In Bad Company: America's Terrorist Underground. Boston: Northeastern University Press.

Hamm, M. S, Spaaij, R. (2017). The Age of Lone Wolf Terrorism, Colombia University Press.

Hemmingby, C, Bjørgo, T. (2016). The Dynamics of a Terrorist Targeting Process: Anders B.Breivik and the 22 July Attacks in Norway. London/New York: Palgrave Macmillan. 
Hewitt, C. (2003). Understanding Terrorism in America: From the Klan to Al-Qaeda. New York: Routledge.

Hoffman, B. (2006). Inside Terrorism. New York: Columbia University Press.

Jenkins, B. (2011). Stray Dogs and Virtual Armies: Radicalization and Recruitmentto Jihadist Terrorism in the United States since 9/11. Santa Monica, CA: RAND.

Joscelyn, T. (2016). Terror Plots in Germany, France Were 'remote-Controlled' by Islamic State Operatives. FDD's Long War Journal. Available at: http://www.longwarjournal.org/archives/2016/09/terror-plots-in-germany-france-were-remote-controlled-by-islamic-state-operatives.php. [Accessed 1 March, 2019].

Krstic, M. (2018). Terrorism lone wolf, Bezbednost, iss1, vol 60, Beograd.

Malthaner, S, Waldmann, P. (2014). “The Radical Milieu: Conceptualizing the Supportive Social Environment of Terrorist Groups." Studies in Conflict $\mathcal{E}$ Terrorism 37(12).

Malthaner, S. et al. (2017). "D5.4 Lone Actor Radicalisation Subscript", FP7 PRIME Project.

McCauley, S, Moskalenko, S. (2014). “Toward a profile of lone-wolf terrorists: What moves an individual from radical opinion to radical action?" Terrorism and Political Violence, 26, no. 1.

McLagan, G, Lowles, N. (2000). Mr. Evil: The Secret Life of Racist Bomber and Killer David Copeland. London: John Blake Publishing.

NYPD. (2014). Threat to U.S. 'Growing Exponentially with ISIS.' CBS News, September 11.Available at: https://www.cbsnews.com/news/terrorthreat-to-us-growing-exponentially-with-isis-nypd-says/. [Accessed 5 May 2019].

Pantucci, R. (2011). "A Typology of Lone Wolves: PreliminaryAnalysis of Lone Islamist Terrorists". The International Centre for the Study of Radicalisation and Political Violence, London.

Petersmann, S. (2019). Christchurch: the myth of the lone wolf attacker, DW. Available at: https://www.dw.com/en/christchurch-the-myth-of-thelone-wolf-attacker/a-47970011. [Accessed 22 April 2019].

Simon, J. (2013). Lone Wolf Terrorism: Understanding the Growing Threat. Amherst, NY: Prometheus Books.

Seierstad, A. (2016). Is Norwegian mass murderes Anders Breivik still a threat to Europe? Newsweek. Available at: https://www.newsweek.com/anders-breivik-neo-nazi-suing-norway-asne-seierstad-447247.

[Accessed 2 March 2019]. 
Schuurman, B, et al. (2017). "Lone Actor Terrorist Attack Planning and Propaganda: A Data Driven Analysis.", Journal of Forensic Sciences, Available at: 10.1111/1556-4029.13676. [Accessed 22 Jan. 2019].

Schuurman, B, et al. (2015). "The Hofstadgroup Revisited: Questioningits Status as a 'Quintessential' Homegrown Jihadist Network". Terrorism and Political Violence 27(5).

Simon, J. D. (2013).'Lone Wolf Terrorism: Understanding the GrowingThreat'. Prometheus Books.

Spaaij, R. (2012). Understanding Lone Wolf Terrorism: Global Patterns, Motivations and Prevention. New York: Springer.

Turpin-Petrosino, C. (2015). Understanding Hate Crime: Acts, Motives, Offenders, Victims, and Justice. New York: Routledge.

White, R. J. (2003). Terrorism: An Introduction. Belmont, CA: Wadsworth. 